\title{
ВМІСТ ЙОДУ В ЩИТОПОДІБНИХ ЗАЛОЗАХ БІЛИХ ЩУРІВ ПРИ ПРИЙМАННІ ЙОДУ ОРГАНІЧНОГО І НЕОРГАНІЧНОГО ЗА УМОВ СУБКЛІНІЧНОГО ГІПЕРТИРЕОЗУ
}

Вступ. Йод як складова тиреоїдних гормонів накопичується в щитоподібних залозах. Це дозволяє досліджувати фрункціональну активність щитоподібних залоз, орієнтуючись на показники вмісту йоду в їх тканині.

Мета дослідження - за умов субклінічного гіпертиреозу дослідити вплив йоду органічного $i$ неорганічного на його вміст у тканині щитоподібних залоз.

Методи дослідження. Білі нелінійні щури-самці (n=90) з початковою масою тіла 140-160 г упродовж 30-ти днів перебування на ізокалорійному крохмально-казеїновому йододефріцитному раціоні з харчовою сумішшю приймали мінімально діючу, помірну та велику дози йоду (21, 50, 100 мкг/ка маси тіла) з калію йодидом (йод неорганічний) або йодобілковим препаратом із чорноморської червоної водорості фрілофори ребристої (йод органічний). Вміст йоду в тканині щитоподібних залоз (абсолютний, відносний та 3 розрахунку на 100 г маси тіла) визначали, використовуючи принцип методу L. Winkler у модиорікації J. F. Sadusk, Jr., \& E. G. Ball.

Результати й обговорення. Вміст йоду в щитоподібних залозах залежав від його хімічної природи та дози. Приймання 21 мкг/кг маси тіла йоду органічного викликало різке зростання його вмісту в щитоподібних залозах; зі збільшенням спожитої дози йодонакопичувальна здатність органа зменшувалася. Вміст йоду в щитоподібних залозах при прийманні 21, 50 і 100 мкг/кг маси тіла йоду неорганічного був значно нижчим, ніж при споживанні аналогічної кількості йоду органічного. Споживання великої (100 мкг/кг маси тіла) дози йоду обох йодовмісних речовин супроводжувалося зменшенням його вмісту в тканині щитоподібних залоз.

Висновки. За умов субклінічного гіпертиреозу споживання йоду органічного значно збільшує вміст йоду в тканині щитоподібних залоз, вплив йоду неорганічного є менш вираженим. Найкращі передумови для зростання фрункціональної активності щитоподібних залоз створює приймання мінімально діючої дози (21 мкг/кг маси тіла) йоду органічного і мінімально діючої та помірної доз (21 і 50 мкг/кг маси тіла) йоду неорганічного. Найнижчу фрункціональну активність щитоподібних залоз можна очікувати в щурів, які споживали йод органічний і неорганічний у великій дозі (100 мкг/кг маси тіла).

КЛЮчОВІ СЛОВА: щитоподібні залози; гіпертиреоз; йод органічний; йод неорганічний; ефект Вольфа - Чайкова.

ВСТУП. Йод як субстрат для синтезу тиреоїдних гормонів (ТГ) має вирішальне значення для морфрофрункціонального стану щитоподібних залоз (Щ3) [1-3]. З об'єктів зовнішнього середовища він потрапляє в щ3, де після окиснення до йодиду зазнає низки перетворень; у клітинах фролікулярного епітелію його концентрація у 20-50 разів більша, ніж у плазмі [4]. При надмірно високому вмісті йодиду в тироцитах авторегуляторне блокування гормонопоезу досягається інгібуванням процесу окиснення, що становить суть ефекту Вольфа - Чайкова [5, 6]. Біосинтез ТГ відбувається в декілька послідовних етапів і закінчується утворенням тироксину (Т4) та три-

(c) О. І. Рябуха, 2020. йодтироніну (Т3), вміст йоду в молекулярній масі яких становить, відповідно, 65 і 59 \% [7, 8]. Вплив ТГ на організм потужний і різноплановий [9]. Основним механізмом їх дії є стимулювання синтезу протеїнів уцитоплазмі клітин і підвищення рівня споживання кисню тканинами. Підвищуючи потребу тканин у кисні й посилюючи в організмі енергетичні процеси, всмоктування та утилізацію глюкози, ТГ мають вирішальне значення для росту і дисеренціювання тканин [10-13]. Розлади діяльності щ3 зумовлюють порушення калоригенезу, обміну речовин, діяльності всіх систем організму, зниження загальної резистентності й антистресової стійкості $[14,15]$, порушення когнітивних, поведінкових та інтелектуально-мнестичних фрункцій тощо [16]. 
У наукових публікаціях, присвячених вивченню ТГ при розладах діяльності ЩЗ, увагу приділяють переважно різноманітним аспектам гіпотиреозу; водночас не менш важливою є проблема гіпертиреозу (ГТ) $[17,18]$. Підвищення активності щ3 супроводжується низкою реакцій і процесів, які змінюють стан організму: додаткове виділення в кров незначної кількості ТГ при помірному активізуванні залоз сприяє посиленню анаболічного ефректу, натомість виділення великої їх кількості активізує процеси катаболізму. На френомені пригнічення діяльності щЗ сполуками йоду при гіпертиреозі ґрунтується один із підходів впливу на орган при цій патології та передопераційній підготовці пацієнтів при дисузному токсичному зобі: після того як досягнуто ефректу, який полягає в зниженні рівня ТГ у крові, приймання йодовмісного засобу припиняють. В останні роки, у зв'язку зі зростанням медичного та соціального значення тиреоїдної патології [19], розширюються дослідження різноманітних аспектів впливу на щз йоду неорганічного (ЙН), а також йоду органічного (ЙО) [20-22]. 3 огляду на дані щодо наявності певних відмінностей у впливі ЙО і ЙН на процеси синтезу ТГ $[23,24]$, продовження вивчення впливу йоду різної хімічної природи на специфрічну діяльність ЩЗ при їх різній фрункціональній активності $\epsilon$ вельми доцільним.

Мета дослідження - за умов субклінічного гіпертиреозу дослідити вплив йоду органічного і неорганічного на його вміст у тканині щитоподібних залоз.

МЕТОДИ ДОСЛІДЖЕННЯ. З 90 білих нелінійних щурів-самців з початковою масою тіла 140-160 г було сорормовано 9 груп (8 експериментальних і одну контрольну) по 10 тварин у кожній. Щурів експериментальних груп утримували на ізокалорійному крохмально-казеїновому раціоні. Водорозчинні вітаміни надходили в раціон зі стандартним вітамінним розчином, жиророзчинні вітаміни й $\alpha$-токофрерол - із нерафінованою соняшниковою олією, макро- та мікроелементи - із сольовою сумішшю J. H. Jones \& C. Foster, з якої було вилучено солі йоду. Всі харчові інгредієнти вводили в раціон відповідно до норм для тварин даного виду і віку. Клітки, в яких утримували тварин, прибирали щодня; корм у годівниці кожної клітки закладали після прибирання. Напувалки в клітках заповнювали дистильованою водою, до якої щури мали вільний доступ (ad libitum).

Модель ГТ створювали за допомогою тиреоїдину (ООО “Белгородвитамины", РФ). Йод неорганічний надходив із калію йодидом, що $€$ традиційним засобом впливу на щз, йод органічний - із йодобілковим препаратом, який було отримано в Одеському фрізико-хімічному інституті ім. О. В. Богатського НАН України з чорноморської червоної водорості фрілосоори ребристої (Phyllophora nervosa); йод у препараті міститься в кількості до 2 \% і перебуває у формі зв'язаних із рослинними протеїнами йодамінокислот [25]. Йодовмісні речовини додавали в раціон у кількості, яка забезпечувала потрапляння в організм гістологічно підтверджених доз йоду: мінімально діючої (21 мкг/кг маси тіла), помірної (50 мкг/кг маси тіла), великої (100 мкг/кг маси тіла).

щури 1-ї групи, які отримували повноцінний загальновіварний корм, були універсальним контролем К1 для тварин інших груп. Щури 2-9 груп перебували на йододесріцитному ізокалорійному крохмально-казеїновому раціоні. Щоб створити умови для розвитку субклінічного ГТ, у корм тварин 3-9 груп додавали тиреоїдин у гістологічно визначеній дозі 15 мг/100 г маси [26]. Оскільки ЩЗ чутливі до впливу стресу, було дотримано фрізіологічного шляху надходження препарату в організм у складі харчової суміші. В їжу тварин 2-3 груп йодовмісні речовини не надходили; вони слугували контролями К2 та К3 для визначення вмісту йоду в щЗ при впливі тиреоїдину і досліджуваних йодовмісних засобів. Раціон щурів 4-6 груп збагачували, відповідно, 21,50 та 100 мкг ЙО; тварини 7-9 груп отримували аналогічну кількість ЙН. Умови дослідження наведено в таблиці 1.

Після закінчення 30-денного періоду спостереження кожну тварину індивідуально зважували на лабораторній вазі (похибка вимірювання $\pm 0,5$ г). Після того як щурів декапітували під ефірним наркозом, їх щз було ретельно відсепаровано від сполучної тканини і зважено на торсійній вазі ВТ-500 (похибка визначення $\pm 1,0$ мг). На всіх етапах дослідження дотримувались принципів біоетики відповідно до Європейської конвенції про захист хребетних тварин, що використовуються для дослідних та інших наукових цілей (Страсбург, 1986), Директиви Ради Європи 2018/63/CV, Закону України "Про захист тварин від жорстокого поводження" (від 21.02.2006 р. № 3447-IV, ст. 26).

Кількісне визначення йоду проводили, використовуючи принцип методу L. Winkler у модифрікації J. F. Sadusk, Jr., \& E. G. Ball: йодиди щз окиснюються бромною водою до йодатів (1); у подальшому при додаванні калію йодиду виділяється вільний йод (2), кількість якого визначають об'ємним методом, застосовуючи розчин натрію тіосульфрату (3):

$$
\begin{aligned}
& \mathrm{I}^{-}+3 \mathrm{Br}_{2}+3 \mathrm{H}_{2} \mathrm{O} \rightarrow \mathrm{IO}_{3}^{-}+6 \mathrm{HBr} \\
& \mathrm{IO}_{3}^{-}+5 \mathrm{I}^{-}+6 \mathrm{H}^{+} \rightarrow 3 \mathrm{I}_{2}+3 \mathrm{H}_{2} \mathrm{O} \\
& 3 \mathrm{I}_{2}+6 \mathrm{Na}_{2} \mathrm{~S}_{2} \mathrm{O}_{3} \rightarrow 6 \mathrm{I}^{-}+3 \mathrm{Na}_{2} \mathrm{~S}_{4} \mathrm{O}_{6}+6 \mathrm{Na}^{+} .
\end{aligned}
$$


Таблиця 1 - Умови проведення дослідження з визначення впливу йоду органічного і неорганічного на вміст йоду в щитоподібних залозах щурів $(n=90)$

\begin{tabular}{|c|c|c|c|c|c|}
\hline Група тварин & $\begin{array}{c}\text { Умови } \\
\text { харчування }\end{array}$ & $\begin{array}{c}\text { Кількість } \\
\text { тиреоїдину } \\
\text { в раціоні, } \\
\text { мг/100 г маси тіла }\end{array}$ & $\begin{array}{l}\text { Фонова кількість } \\
\text { йоду в раціоні, } \\
\text { мкг/щура/добу }\end{array}$ & $\begin{array}{c}\text { Хімічна природа } \\
\text { йоду в раціоні }\end{array}$ & $\begin{array}{c}\text { Кількість йоду, } \\
\text { введеного } \\
\text { в раціон, мкг/кг } \\
\text { маси тіла }\end{array}$ \\
\hline 1-ша (K1) (n=10) & \multicolumn{5}{|c|}{ Повноцінний загальновіваріальний корм } \\
\hline 2-га (K2) $(n=10)$ & ІККЙР & - & $1,6-1,8$ & - & - \\
\hline 3-тя (К3) $(\mathrm{n}=10)$ & ІККЙР & 15 & $1,6-1,8$ & - & - \\
\hline 4-та $(n=10)$ & ІККЙР & 15 & $1,6-1,8$ & Органічна & 21 \\
\hline 5-та $(n=10)$ & ІККЙР & 15 & $1,6-1,8$ & Органічна & 50 \\
\hline 6-та $(n=10)$ & ІККЙР & 15 & $1,6-1,8$ & Органічна & 100 \\
\hline 7-мa $(n=10)$ & ІККЙР & 15 & $1,6-1,8$ & Неорганічна & 21 \\
\hline 8-ма $(n=10)$ & ІККЙР & 15 & $1,6-1,8$ & Неорганічна & 50 \\
\hline 9-та $(n=10)$ & ІККЙР & 15 & $1,6-1,8$ & Неорганічна & 100 \\
\hline
\end{tabular}

Примітка. ІККЙР - ізокалорійний крохмально-казеїновий йододефріцитний раціон.

Абсолютний вміст йоду в ЩЗ визначали за кількістю натрію тіосульсрату, яку було використано для титрування. Розрахунок здійснювали 3 огляду на те, що на визначення 1 мкг йоду потрібно 0,0474 мл 0,001н розчину натрію тіосульфрату. Тоді абсолютний вміст йоду в досліджуваній наважці щ3 визначали за фрормулою (4):

$$
x=\frac{a \cdot c \cdot 1}{b \cdot 0,0474}
$$

де $x$ - абсолютна кількість йоду в досліджуваній наважці (мкг);

a - кількість 0,001 н розчину натрію тіосульфату, яку було витрачено на титрування досліджуваної проби (мл);

$b$ - маса досліджуваної наважки (мг);

c-маса досліджуваної щитоподібної залози (Мг);

0,0474 - кількість 0,001н розчину натрію тіосульфату, якубуловитрачено натитрометричне визначення 1 мкг йоду (мл);

I - кількість йоду, яка відповідає 0,0474 мл 0,001 н розчину натрію тіосульсрату (мкг).

Додатково визначали відносний (на 100 г маси залози) вміст йоду в ЩЗ та вміст йоду в ЩЗ із розрахунку на 100 г маси тіла щура.

Кількісні параметри, які було отримано в результаті дослідження, оброблено методом математичної статистики з використанням ліцензійної програми StatSoft Statistica v6.0 (serial 31415926535897) з визначенням середнього арифметичного $(\bar{X})$ і похибки середнього арифрметичного (m); статистично значимими вважали відмінності при $p \leq 0,05$. Вплив ЙО та ЙН на вміст йоду в ЩЗ визначали, порівнюючи параметри, одержані при споживанні зростаючих доз йоду тієї самої хімічної природи, ідентичних доз йоду різної (органічної і неорганічної) хімічної природи, з результатами, отриманими в контрольних групах К3 та К1.
РЕЗУЛЬТАТИ Й ОБГОВОРЕННЯ. ЦИфрові показники, отримані під час дослідження, наведено в таблиці 2. Установлено, що вміст йоду в тканині щ3 щурів 3-ї групи був вірогідно більшим, ніж в інтактних тварин 1-ї групи та щурів 2-ї групи, які не отримували тиреоїдину $(p<0,001-p<0,05)$. Так, його абсолютний показник становив $(8,66 \pm 0,62)$ мкг, відносний - $(61,794 \pm 0,990)$ мкг, вміст йоду в залозах у розрахунку на 100 г маси тіла тварини - $(4,26 \pm 0,17)$ мкг (порівняно 3 параметрами щурів контрольних груп К1 та К2 $p<0,001-p<0,05)$.

Споживання 21 мкг Йо щурами 4-ї групи супроводжувалося значним збільшенням усіх досліджуваних показників вмісту йоду в тканині щ3 порівняно зі значеннями аналогічних параметрів як в інтактних тварин $(p<0,001)$, так і в щурів контрольної групи К3 $(p<0,001)$. При прийманні 50 мкг ЙО (5-та група) показники відносного вмісту йоду в щЗ були нижчими $(p<0,001)$, а його абсолютний вміст і кількість йоду в залозах у розрахунку на 100 г маси тіла вищими $(p<0,001)$, ніж значення аналогічних показників у тварин контрольної групи КЗ. Водночас вони були нижчими, ніж у щурів попередньої 4-ї групи, харчовий раціон яких збагачували меншою кількістю (21 мкг) йо $(p<0,001)$. Подальше збільшення дози спожитого ЙО до 100 мкг (6-та група) супроводжувалося зменшенням кількостійоду в залозаху розрахунку на 100 г маси тіла (щодо значення аналогічного показника в щурів попередніх 4-5 груп $p<0,001)$. Відносний вміст йоду в щЗ тварин 6-ї групи був нижчим, ніж у контрольній групі КЗ $(p<0,001)$, і практично не відрізнявся від такого в щурів 5-ї групи ( $p>0,05)$.

Введення у раціон щурів 7-ї групи 21 мкг ЙН викликало вірогідне зменшення, порівняно 3 показником тварин контрольної групи К3, 
Таблиця 2 - Вплив йоду органічної і неорганічної хімічної природи на вміст йоду в тканині щитоподібних залоз щурів за умов субклінічного гіпертиреозу (n=90)

\begin{tabular}{|c|c|c|c|c|c|c|}
\hline \multirow[b]{2}{*}{$\begin{array}{c}\text { Група } \\
\text { тварин }\end{array}$} & \multirow{2}{*}{$\begin{array}{c}\text { Кількість } \\
\text { тиреоїдину, який } \\
\text { додавали до } \\
\text { раціону, } \\
\text { мг/100 г маси тіла }\end{array}$} & \multirow{2}{*}{$\begin{array}{c}\text { Хімічна } \\
\text { природа } \\
\text { йоду, який } \\
\text { додавали } \\
\text { до раціону }\end{array}$} & \multirow{2}{*}{$\begin{array}{c}\text { Кількість йоду, } \\
\text { який } \\
\text { додавали } \\
\text { до раціону, } \\
\text { мкг/кг }\end{array}$} & \multicolumn{3}{|c|}{ Вміст йоду в щитоподібних залозах } \\
\hline & & & & $\begin{array}{c}\text { абсолютний, } \\
\text { мкг } \\
\overline{\mathrm{X}} \pm \mathrm{m}\end{array}$ & $\begin{array}{c}\text { відносний, } \\
\text { Мкг } \\
\overline{\mathrm{X}} \pm \mathrm{m}\end{array}$ & $\begin{array}{c}\text { на } 100 \text { г маси } \\
\text { тіла, мкг } \\
\bar{X} \pm m\end{array}$ \\
\hline $\begin{array}{l}\text { 1-ша (K1) } \\
(n=10)\end{array}$ & \multirow{2}{*}{\multicolumn{3}{|c|}{ Повноцінний загальновіваріальний корм }} & $4,79 \pm 0,34$ & $29,00 \pm 1,09$ & $2,49 \pm 0,15$ \\
\hline $\begin{array}{l}\text { 2-га (K2) } \\
(\mathrm{n}=10)\end{array}$ & & & & $7,94 \pm 0,33$ & $19,69 \pm 0,24$ & $2,09 \pm 0,22$ \\
\hline $\begin{array}{l}\text { 3-тя (К3) } \\
(n=10)\end{array}$ & 15 & \multicolumn{2}{|c|}{ Не давали } & $\begin{array}{c}8,66 \pm 0,62 \\
p<0,001(1) \\
p<0,05(2)\end{array}$ & $\begin{array}{c}61,79 \pm 0,99 \\
p<0,001(1) \\
p<0,01(2)\end{array}$ & $\begin{array}{l}4,26 \pm 0,17 \\
p<0,05(1) \\
p<0,01(2)\end{array}$ \\
\hline $\begin{array}{l}\text { 4-та } \\
(n=10)\end{array}$ & 15 & Органічна & 21 & $\begin{array}{l}20,81 \pm 1,73 \\
p<0,001(1) \\
p<0,001(3)\end{array}$ & $\begin{array}{l}100,50 \pm 0,59 \\
p<0,001(1) \\
p<0,001(3)\end{array}$ & $\begin{array}{c}8,53 \pm 1,18 \\
p<0,001(1) \\
p<0,001(3)\end{array}$ \\
\hline $\begin{array}{l}\text { 5-та } \\
(n=10)\end{array}$ & 15 & Органічна & 50 & $\begin{array}{l}12,41 \pm 1,06 \\
p<0,001(1) \\
p<0,001(3)\end{array}$ & $\begin{array}{l}58,75 \pm 0,59 \\
p<0,001(1) \\
p<0,001(3)\end{array}$ & $\begin{array}{c}6,09 \pm 0,26 \\
p<0,001(1) \\
p<0,001(3)\end{array}$ \\
\hline $\begin{array}{l}\text { 6-та } \\
(n=10)\end{array}$ & 15 & Органічна & 100 & $\begin{array}{c}9,09 \pm 0,71 \\
p<0,001(1) \\
p<0,001(4) \\
p<0,001(5)\end{array}$ & $\begin{array}{l}58,21 \pm 0,43 \\
p<0,001(1) \\
p<0,001(3) \\
p<0,001(4)\end{array}$ & $\begin{array}{c}3,53 \pm 0,34 \\
p<0,001(1) \\
p<0,001(4) \\
p<0,001(5)\end{array}$ \\
\hline $\begin{array}{l}\text { 7-ма } \\
(n=10)\end{array}$ & 15 & Неорганічна & 21 & $\begin{array}{l}11,07 \pm 1,55 \\
p<0,001(1) \\
p<0,001(4)\end{array}$ & $\begin{array}{l}52,16 \pm 0,97 \\
p<0,001(1) \\
p<0,001(3) \\
p<0,001(4)\end{array}$ & $\begin{array}{c}5,78 \pm 0,45 \\
p<0,001(1) \\
p<0,001(3) \\
p<0,05(4)\end{array}$ \\
\hline $\begin{array}{l}\text { 8-ма } \\
(n=10)\end{array}$ & 15 & Неорганічна & 50 & $\begin{array}{c}11,04 \pm 0,44 \\
p<0,001(1) \\
p<0,05(3)\end{array}$ & $\begin{array}{l}54,10 \pm 0,99 \\
p<0,001(1) \\
p<0,001 \\
p<0,001\end{array}$ & $\begin{array}{c}5,36 \pm 0,19 \\
p<0,001(1) \\
p<0,001(3) \\
p<0,001(5)\end{array}$ \\
\hline $\begin{array}{l}\text { 9-та } \\
(n=10)\end{array}$ & 15 & Неорганічна & 100 & $\begin{array}{c}8,25 \pm 0,34 \\
p<0,001(1) \\
p<0,05(8)\end{array}$ & $\begin{array}{l}47,11 \pm 0,63 \\
p<0,001(1) \\
p<0,001(3) \\
p<0,001(6) \\
p<0,001(7) \\
p<0,001(8)\end{array}$ & $\begin{array}{l}3,65 \pm 0,14 \\
p<0,001(1) \\
p<0,001(3) \\
p<0,001(7) \\
p<0,001(8)\end{array}$ \\
\hline
\end{tabular}

Примітки:

1. $\overline{\mathrm{X}}$ - середнє арифмметичне.

2. m - стандартна похибка середнього арифметичного.

3. p - ступінь вірогідності; цифри в дужках вказують на номер групи, відносно якої вирахувано коефріцієнт р; показників $p>0,05$ до таблиці не вносили.

відносного вмісту йоду в їх щ3 ( $p<0,001)$. Окрім того, ЩЗ щурів цієї групи містили менше йоду, ніж залози тварин 4-ї групи, які споживали тотожну кількість ЙО, - порівняння між собою цисррових значень усіх досліджуванихпараметрів довело їх вірогідну відмінність $(p<0,001-p<0,05)$. Показники вмісту йоду в щЗ тварин 8-ї групи, в раціон яких вводили 50 мкг ЙН, практично не відрізнялися від таких у щурів 7-ї групи ( $>>0,05)$; залози тварин даної групи містили менше йоду, ніж залози щурів 5-ї групи, які споживали 50 мкг ЙО $(p<0,001)$. Відносний вміст йоду в щЗ та вміст йоду в залозах у розрахунку на 100 г маси тіла в щурів 9-ї групи, які приймали 100 мкг ЙН, були вірогідно меншими, ніж у тварин контрольної групи К3 та щурів 7-8 груп ( $<<0,001)$. Окрім того, при порівнюванні впливу 100 мкг ЙН та ЙО на відносний вміст йоду в щЗ установлено, що показники відносного вмісту йоду в тканині щЗ щурів 9-ї групи були вірогідно меншими, ніж у тварин 6-ї групи, раціон яких збагачували аналогічною кількістю ЙО $(p<0,001)$.

Отже, проведені дослідження підтвердили, що приймання тиреоїдину в дозі 15 мг/100 г маси тіла викликало в щурів явища ГТ: на підвищення специфрічної активності щ3 тварин 3-ї групи вказувало виразне (щодо параметрів інтактних тварин та щурів, які перебували в умовах йододесріциту) збільшення вмісту йоду в тканині їх щ3. Результат додаткового стимулювання діяльності ЩЗ прийманням йоду був пов'язаний із хімічною природою спожитого йоду та його 
дозою, що підтвердило залежність специфічної діяльності Щ3, встановлену раніше [23, 24]. Введення у раціон щурів 21 мкг обох йодовмісних препаратів викликало різке зростання циоррових показників вмісту йоду в залозах, що логічно вважати ознакою значного активізування гормональної діяльності. Йодонакопичувальна здатність щз зменшувалася зі збільшенням дози спожитого йоду. Це вказує на пригнічення специфрічної активності ЩЗ високою дозою йоду при ГТ, що свідчить про наявність ефекту Вольфра - Чайкова. Водночас цифрові показники відносного вмісту йоду в тканині залоз тварин, які приймали 50 і 100 мкг ЙО, перебували на одному рівні ( $>0,5)$, що може бути ознакою схожого перебігу процесів перетворення йоду при прийманні цих доз. Вміст йоду в тканині щЗ при прийманні досліджуваних доз (21, 50 і 100 мкг) ЙН був значно меншим, ніж при споживанні аналогічної кількості ЙО. Найнижчі цисрові показники вмісту йоду в щЗ відзначали в щурів, які споживали ЙО та ЙН у великій дозі (100 мкг).

\section{СПИСОК ЛІТЕРАТУРИ}

1. Iodide effects on the thyroid: biochemical, physiological, pharmacological, and clinical effects of iodide in the thyroid / V. Panneels, G. Juvenal, J. M. Boeynaems [et al.] // V. R. Preedy, G. N. Burrow, R. R. Watson - eds. Comprehensive Handbook of lodine: Nutritional, Biochemical, Pathological and Therapeutic Aspects. - New York: Academic Press, 2009. - ch. 32, pp. 303-314.

2. Кравченко В.І.Біологічна роль йоду та йодна недостатність як патогенетичний срактор виникнення тиреоїдної патології у вагітних та її профрілактика / В. І. Кравченко, Б. К. Медведєв // Міжнар. ендокрин. журн. - 2018. - 14, № 2. - С. 111-118.

3. Moini J. lodine and thyroid hormones / J. Moini, K. Pereira, M. Samsam // J. Moini, K. Pereira, M. Samsam. Epidemiology of Thyroid Disorders. - Philadelphia: Elsevier, 2020. - ch. 3. - pp. 45-62.

4. Alves M. L. D. The thyroid gland / M. L. D. Alves / Annals Thyroid Res. - 2019. - 5, No. 1. - P. 185-187.

5. Al-Tamimi H.J. The Wolff - Chaikoff effect ameliorates heat stress in rats / $\mathrm{H}$. J. Al-Tamimi, A. Al-Dawood, Z. Mahasneh // Anim. Biotelemetry. - 2019. - 7. - P. 8.

6. Chung H. R. lodine and thyroid function. Ann. Pediatr. Endocrinol. Metab. -2014. - 19, No. 1. - P. 8-12.

7. Lúcia M. About iodide: a friendly and necessary ion / M. Lúcia, A. M. Navarro // Annals. Thyroid. Res. 2019. - 5, No. 3. - P. 223-228.

8. Barbaro D. lodine and myo-inositol: a novel promising combination for iodine deficiency / D. Barbaro, B. Orrù, V. Unfer // Front. Endocrinol. (Lausanne). 2019. - 10. - P. 457.
ВИСНОВКИ. За умов субклінічного гіпертиреозу споживання йоду органічного значно збільшує вміст йоду в тканині щитоподібних залоз, вплив йоду неорганічного $€$ менш вираженим. Найкращі передумови для зростання фрункціональної активності щитоподібних залоз створює приймання мінімальної дози (21 мкг/кг маси тіла) йоду органічного і незначної та помірної доз (21 і 50 мкг/кг маси тіла) йоду неорганічного. Найнижчу фрункціональну активність щитоподібних залоз можна очікувати в щурів, які споживали йод органічнийінеорганічний у великій дозі (100 мкг/кг маси тіла).

Перспективи подальших досліджень полягають у поглибленому вивченні впливу йоду різної хімічної природи на секреторну діяльність щитоподібних залоз.

Зв'язок роботи з науковими програмами, планами, темами. Роботає складовою частиною науково-дослідної теми “Патогенетичні аспекти фрормування алергічних і запальних процесів, впливів на реактивність організму та фрармакотерапія" (№державноїреєстрації0111U000126).

9. Mendoza A. New insights into thyroid hormone action / A. Mendoza, A. N. Hollenberg // Pharmacol. Ther. - 2017. - No. 173. - P. 135-145.

10. Thyroid hormones crosstalk with growth factors: Old facts and new hypotheses / E. Candelotti, P. De Vito, R. G. Ahmed [et al.] // Immun. Endoc. \& Metab. Agents in Med. Chem. - 2015. - 15, No. 1. - P. 71-85.

11. van der SpekA. H. The classic pathways of thyroid hormone metabolism / A. H. van der Spek, E. Fliers, A. Boelen // Mol. Cell. Endocrinol. -2017. -458. -P. 29-38.

12. Bhagavan N. V. Endocrine metabolism IV: Thyroid gland / N. V. Bhagavan, C.-E. Ha // Essentials of Medical Biochemistry. - 2nd ed. - New York: Academic Press, 2018. - ch. 31, pp. 577-588.

13. Cicatiello A. G. Metabolic effects of the intracellular regulation of thyroid hormone: old players, new concepts / A. G. Cicatiello, D. Di Girolamo, M. Dentice // Front. Endocrinol. (Lausanne). - 2018. - 9. - P. 474.

14. Mullur R. Thyroid hormone regulation of metabolism / R. Mullur, Y.-Y. Liu, G. A. Brent // Physiol. Rev. 2014. - 94, No. 2. - P. 355-382.

15. Городецкая И. В. Перифрерические механизмы стресс-протекторного эфрфекта йодсодержащих гормонов щитовидной железы / И. В. Городецкая, Е. А. Гусакова, О. В. Евдокимова // Вестн. ВГМУ. -2016. - 15, № 6. - C. 41-53.

16. Melse-BoonstraA. lodine deficiency in pregnancy, infancy and childhood and its consequences for brain development/A. Melse-Boonstra, N. Jaiswal // Best Pract. \& Res. Clin. Endocrinol. \& Metab. - 2010. - 24, No 1. P. 29-38. 
17. Péter F. Congenital disorders of the thyroid: hypo/ hyper / F. Péter, A. Muzsnai // Pediatr Clin North Am. 2011. - 58, No. 5, 1099-1115.

18. Samsam M. Hyperthyroidism / M. Samsam // J. Moini, K. Pereira, M. Samsam. Epidemiology of Thyroid Disorders. - Philadelphia: Elsevier, 2020. - ch. 6. pp. 121-145.

19. Маменко М. Є. Йодний дефріцит та йододефріцитні захворювання (лекції) / М. Є. Маменко // Перинатология и педиатрия. - 2013. - № 1. - С. 97-105.

20. Безруков О. Ф. Возможности и перспективы профилактики йодной недостаточности (обзор) / О. Ф. Безруков // Крим. терапевт. журн. - 2011. - № 2. C. 4-7.

21. Исследование профилактической эффрективности биологически активной добавки Биойод / Л. С. Большакова, Е. В. Литвинова, А. В. Кузина [и др.] // Фундаментальные исследования. - 2013. № 10, ч. 11. - С. 2401-2404.

22. Копчак Н. Г. Вплив йоду на показники ліпідного профрілю крові щурів різного віку при експериментальному ожирінні / Н. Г. Копчак, О. С. Покотило,
М. Д. Кухтин, М. І. Коваль // Мед. та клініч. хімія. 2017. - 19, № 4 (73). - С. 123-128.

23. Рябуха О. І. Ультраструктурні особливості синтетичної діяльності сролікулярних тироцитів при прийманні органічного йоду в умовах аліментарного йододефріциту / О. І. Рябуха // Вісн. проблем біології і медицини. - 2017. - 2 (140), вип. 4. - С. 134-139.

24. Рябуха О. І. Дослідження синтетичної діяльності фолікулярних тироцитів при прийманні неорганічного йоду в умовах аліментарного йододефіциту / О. І. Рябуха // Вісн. проблем біології і медицини. 2017. - 3 (141), вип. 4. - С. 218-223.

25. Рябуха О. І. До питання застосування при гіпотиреозі неорганічного та органічного йоду (огляд) / О. І. Рябуха // Актуальні проблеми трансп. медицини. 2018. - № 2 (52). - C. 7-21.

26. Ryabukha $\mathrm{O}$. Applying regression analysis to study the interdependence of thyroid, adrenal glands, liver, and body weight in hypothyroidism and hyperthyroidism / O. Ryabukha, I. Dronyuk // CEUR Workshop Proc. - 2019. - 2488. - P. 155-164.

\section{REFERENCES}

1. Panneels, V., Juvenal, G., Boeynaems, J.M., Dumont, J.E. \& Van Sande J. (2009). lodide effects on the thyroid: biochemical, physiological, pharmacological, and clinical effects of iodide in the thyroid. Preedy, V.R., Burrow, G.N., Watson, R.R. (Eds.). Comprehensive Handbook of lodine: Nutritional, Biochemical, Pathological and Therapeutic Aspects (pp. 303-314). New York: Academic Press.

2. Kravchenko, V.I. \& Medvedev B.K. (2018). Biolohichna rol yodu ta yodna nedostatnist yak patohenetychnyi faktor vynyknennia tyreoidnoi patolohii u vahitnykh ta yii profilaktyka [The biological role of iodine and iodine deficiency as pathogenetic factor of thyroid pathology in pregnant women and its prevention]. Mizhnarodnyi endokrynolohichnyi zhurnal - International Journal of Endocrinology, 14 (2), 111-118 [in Ukrainian].

3. Moini J., Pereira, K., \& Samsam, M. (2020). Iodine and thyroid hormones. Epidemiology of Thyroid Disorders. Philadelphia: Elsevier.

4. Alves, M.L.D. (2019). The thyroid gland. Annals Thyroid Res., 5 (1), 185-187.

5. Al-Tamimi, H.J., Al-Dawood, A., \& Mahasneh, Z. (2019).The Wolff-Chaikoff effect ameliorates heat stress in rats. Anim. Biotelemetry, 7, 8.

6. Chung, H. R. (2014). lodine and thyroid function. Ann. Pediatr. Endocrinol. Metab., 19 (1), 8-12.

7. Lúcia, M., \& Navarro, A.M. (2019). About iodide: a friendly and necessary ion. Annals. Thyroid. Res, 5(3), 223-228.

8. Barbaro, D., Orrù, B., \& Unfer, V. (2019). Iodine and myo-inositol: a novel promising combination for iodine deficiency. Front. Endocrinol. (Lausanne), 10, 457.

9. Mendoza, A., \& Hollenberg, A.N. (2017). New insights into thyroid hormone action. Pharmacol. Ther., 173, 135-145.
10. Candelotti, E., Vito, P.D., Ahmed, R.G., Luly, P., Davis, P.J., Pedersen, J.Z., ... Incerpi, S. (2015). Thyroid hormones crosstalk with growth factors: Old facts and new hypotheses. Immun. Endoc. \& Metab. Agents in Med. Chem, 15 (1), 71-85.

11. van der Spek, A.H., Fliers, E. \& Boelen A. (2017). The classic pathways of thyroid hormone metabolism. Mol. Cell. Endocrinol., 458, 29-38.

12. Bhagavan, N.V., \& Ha, C.-E. (2018). Endocrine metabolism IV: Thyroid gland. In Essentials of Medical Biochemistry. 2nd ed. New York: Academic Press.

13. Cicatiello, A.G., Di Girolamo, D., \& Dentice, M. (2018). Metabolic effects of the intracellular regulation of thyroid hormone: old players, new concepts. Front. Endocrinol. (Lausanne), 9, 474.

14. Mullur, R., Liu, Y.-Y., \& Brent, G.A. (2014). Thyroid hormone regulation of metabolism. Physiol. Rev., 94 (2), 355-382.

15. Gorodetskaya, I.V., Gusakova, E.A., \& Evdokimova, O.V. (2016). Perifericheskie mekhanizmy stressprotektornogo effekta yodsoderzhashchikh gormonov shchitovidnoy zhelezy [Peripheral mechanisms of the stress-protective effect of iodine-containing thyroid hormones]. Vestnik VGMU - Journal of Vitebsk State Medical University, 15 (6), 41-53 [in Russian].

16. Melse-Boonstra, A., \& Jaiswal, N. (2010). Iodine deficiency in pregnancy, infancy and childhood and its consequences for brain development. Best Pract. \& Res. Clin. Endocrinol. \& Metab, 24 (1), 29-38.

17. Péter, F., \& Muzsnai, A. (2011). Congenital disorders of the thyroid: hypo/hyper. Pediatr. Clin. North Am., 58 (5), 1099-1115.

18. Samsam, M. (2020). Hyperthyroidism. In J. Moini, K. Pereira \& M. Samsam, Epidemiology of Thyroid Disorders. Philadelphia: Elsevier. 
19. Mamenko, M.Ye. (2013). Yodnyi defitsyt ta yododefitsytni zakhvoriuvannia (lektsiia) [lodine deficiency and iodine deficiency disorders (lecture)]. Perinatologiya i pediatriya - Perinatology and Pediatrics, 1, 97-105 [in Ukrainian].

20. Bezrukov, O.F. (2011). Vozmozhnosti i perspektivy profilaktiki yodnoy nedostatochnosti (obzor) [Possibilities and prospectives of iodine insufficiency prophylaxis (a review)]. Krymskyi terapevtychnyi zhurnal - Crimean Journal of Internal Diseases, 2, 4-7 [in Russian].

21. Bolshakova, L.S., Litvinova, E.V., Kuzina, A.V., Lisitsyn, A.B., \& Chernuha, I.M. (2013). Issledovanie profilakticheskoy effektivnosti biologicheski aktivnoy dobavki Bioyod [Study of prophylactic effectiveness of the biologically active additives Bioiodine]. Fundamentalnyye issledovaniya - Fundamental Researches, 10/11, 2401-2404 [in Russian].

22. Kopchak, N.H., Pokotylo, O.S., Kukhtyn, M.D., \& Koval, M.I. (2017). Vplyv yodu na pokaznyky lipidnoho profiliu krovi shchuriv riznoho viku pry eksperymentalnomu ozhyrinni [Influence of iodine on the indicators of lipid profile of rats' blood of different age in experimental obesity]. Medychna ta klinichna khimiia - Medical and Clinical Chemistry, 19 (4), 123-128 [in Ukrainian].

23. Ryabukha, O.I. (2017). Ultrastrukturni osoblyvosti syntetychnoi diialnosi folikuliarnykh tyrotsytiv pry pryimanni orhanichnoho yodu v umovakh alimentarnoho yododefitsytu [Ultrastructural features of the follicular thyrocytes' synthetic activity while taking organic iodine under conditions of alimentary iodine deficiency]. Visnyk problem biolohii i medytsyny - Bulletin of Problems in Biology and Medicine, 4, 2(140), 134-139 [in Ukrainian].

24. Ryabukha, O.I. (2017). Doslidzennia syntetychnoi diialnosti folikuliarnykh tyrotsytiv pry pryimanni neorhanichnoho yodu $v$ umovakh alimentarnoho yododefitsytu [Study of the follicular thyrocytes' synthetic activity while taking inorganic iodine under conditions of alimentary iodine deficiency]. Visnyk problem biolohii i medytsyny - Bulletin of Problems in Biology and Medicine, 4, 3(141), 218-223 [in Ukrainian].

25. Ryabukha, O.I. (2018). Do pytannia zastosuvannia pry hipotyreozi neorhanichnoho ta orhanichnoho yodu (ohliad) [To the problem of application in hypothyrosis inorganic and organic iodine (a review)]. Aktualni problemy transportnoi medytsyny - Actual Problems of Transport Medicine, 2 (52), 7-21 [in Ukrainian].

26. Ryabukha, O., \& Dronyuk, I. (2019). Applying regression analysis to study the interdependence of thyroid, adrenal glands, liver, and body weight in hypothyroidism and hyperthyroidism. CEUR Workshop Proc., 2488, 155-164.

\section{СОДЕРЖАНИЕ ЙОДА В ЩИТОВИДНЫХ ЖЕЛЕЗАХ БЕЛЫХ КРЫС ПРИ ПРИЕМЕ ОРГАНИЧЕСКОГО И НЕОРГАНИЧЕСКОГО ЙОДА В УСЛОВИЯХ СУБКЛИНИЧЕСКОГО ГИПЕРТИРЕОЗА}

\section{Резюме}

Вступление. Йод как составляющая тиреоидных гормонов накапливается в щитовидных железах. Это позволяет исследовать фрунциональную активность щитовидных желез, ориентируясь на показатели содержания йода в их ткани.

Цель исследования - в условиях субклинического гипертиреоза исследовать влияние йода органического и неорганического на его содержание в ткани щитовидных желез.

Методы исследования. Белые нелинейные крысы-самцы (n=90) с начальной массой тела 140-160 г в течение 30-ти дней пребывания на изокалорийном крахмально-казеиновом йододефицитном рационе с пищевой смесью принимали минимально действующую, умеренную и большую дозы йода (21, 50, 100 мкг/кг массы тела) с калия йодидом (йод неорганический) или йодобелковым препаратом из черноморской красной водоросли фриллофоры ребристой (йод органический). Содержание йода в ткани щитовидных желез (абсолютное, относительное и в расчете на 100 г массы тела) определяли, используя принцип метода L. Winkler в модифрикации J. F. Sadusk, Jr., \& E. G. Ball.

Результаты и обсуждение. Содержание йода в щитовидных железах зависело от его химической природы и дозы. Потребление 21 мкг/кг массы тела йода органического вызывало резкое возрастание его содержания в щитовидных железах; с увеличением потребляемой дозы йодоконцентрационная способность органа уменьшалась. Содержание йода в щитовидных железах при приеме 21, 50 и 100 мкг/кг массы тела йода неорганического было значительно ниже, чем при потреблении аналогичного количества йода органического. Потребление большой (100 мкг/кг массы тела) дозы йода обоих йодосодержащих веществ сопровождалось уменьщением его содержания в ткани щитовидных желез. 
Выводы. В условиях субклинического гипертиреоза потребление йода органического значительно увеличивает содержание йода в ткани щитовидных желез, влияние йода неорганического менее выражено. Лучшие предпосылки для возрастания фрункциональной активности щитовидных желез создает прием минимально действующей дозы (21 мкг/кг массы тела) йода органического и минимально действующей и умеренной доз (21 и 50 мкг/кг массы тела) йода неорганического. Самую низкую фрункциональную активность щитовидных желез можно ожидать у крыс, потреблявших йод органический и неорганический в большой дозе (100 мкг/кг массы тела).

КЛЮЧЕВЫЕ СЛОВА: щитовидные железы; гипертиреоз; йод органический; йод неорганический; эфрфект Вольфа - Чайкова.

\author{
O. I. Ryabukha
}

LVIV MEDICAL INSTITUTE

\title{
IODINE CONTENT IN WHITE RATS THYROID GLANDS IN ORGANIC AND INORGANIC IODINE ADMINISTRATION UNDER THE CONDITIONS OF SUBCLINICAL HYPERTHYROIDISM
}

\section{Summary}

Introduction. lodine as a component of thyroid hormones is accumulated in the thyroid gland. This permits to study the thyroid gland functional activity by focusing on the iodine content in its tissue.

The aim of the study - to learn the effect of organic and inorganic iodine on its content in the thyroid gland under the conditions of subclinical hyperthyroidism.

Research Methods. White non-linear male rats $(n=90)$ with an initial body weight of 140-160 g were kept on a iodine-deficient isocaloric starch-casein diet with a food mixture and consumed minimally active, moderate and large doses of iodine (21, 50, $100 \mu \mathrm{g} / \mathrm{kg}$ body weight) with potassium iodide (inorganic iodine) or iodine-protein preparation made of the Black Sea red algae Phyllophora nervosa (DC.) Grev (organic iodine) within the period of 30 days. The iodine content in the thyroid tissue (absolute, relative, and per $100 \mathrm{~g}$ of body weight) was determined using the Winkler procedure principle in J. F. Sadusk, Jr., \& E. G. Ball.

Results and Discussion. The iodine content in the thyroid glands depended on its chemical nature and the dose. Consumption of $21 \mu \mathrm{g} / \mathrm{kg}$ body weight of organic iodine caused a sharp increase of its content in the thyroid glands; with the consumed dose increase, the organ's iodine concentration ability decreased. The iodine content in the thyroid gland when consuming inorganic iodine in the dose of 21, 50 and $100 \mu \mathrm{g} / \mathrm{kg}$ body weight, was significantly less than in consuming the similar amounts of organic iodine. The consumption of the large (100 $\mu \mathrm{g} / \mathrm{kg}$ body weight) dose of iodine in the both iodine-containing substances was accompanied by a decrease of the iodine content in the thyroid gland tissue.

Conclusions. In the conditions of subclinical hyperthyroidism, the intake of organic iodine increases the iodine content in the thyroid gland tissue, the effect of inorganic iodine being less pronounced. The best prerequisites for the thyroid gland functional activity growth are the intake of a minimal dose (21 $\mu \mathrm{g} / \mathrm{kg}$ body weight) of organic iodine and a minimal and moderate dose (21 and $50 \mu \mathrm{g} / \mathrm{kg}$ body weight) of inorganic iodine. The minimal functional activity of the thyroid gland can be expected in rats which consumed a large dose of organic and inorganic iodine (100 $\mu \mathrm{g} / \mathrm{kg}$ body weight).

KEY WORDS: thyroid gland; hyperthyroidism; organic iodine; inorganic iodine; Wolff - Chaikoff effect.

Отримано 10.01.20

Адреса для листування: О. І. Рябуха, Львівський медичний інститут, вул. Поліщука, 76, Львів, 79018, Україна, е-таil: oriabuha@ ukr.net. 